\title{
A Research Journey with Plains Cree Elders Regarding Their Image of the Child
}

\author{
Janine Tine
}

\begin{abstract}
Janine Tine is a PhD Candidate at the University of Alberta. Her early childhood research interests include bicultural childhoods, parental perceptions of childhood and childrearing held by intercultural couples, and Indigenous conceptions of childhood. Prior to completing her master's degree at the U of A, Janine taught grade 2 for six years and gifted education for three. She has a Post-Degree Certificate in Education from the University of Saskatchewan (U of S) and a Bachelor of Education from the Saskatchewan Urban Native Teacher Education Program at the U of S. Email: akerman@ualberta.ca
\end{abstract}

To develop culturally appropriate education for Indigenous children in Canada, knowledge of childhood in Indigenous contexts is needed. This article focuses on the author's learning journey during a community-based participatory research project regarding two Plains Cree Elders' images, or understandings, of the child. To situate the study, the author revisits her research with Elders while exploring some epistemological, ontological, and axiological considerations of Indigenous research and then shares how she employed cultural protocols and forged relationships. Next, the author shares and reflects on the Elders' understandings of childhood and the ways in which she cared for the Elders' knowledge.

Key words: Plains Cree Elders; Indigenous research; cultural protocol; image of the child; early childhood
As educators, our socioculturally constructed images or understandings of the child directly influence the pedagogy we provide for them (Dahlberg, Moss, \& Pence, 2013). How we understand or view the child (e.g., as intelligent, competent, creative) influences how we educate the child and the learning opportunities we provide (Gandini, 2004; Malaguzzi et al., 2016). Understandings employed in early childhood education, however, are often decontextualized from children's everyday cultural, historical, familial, and community lives (Højholt, 2018) and rely instead on teachers universalized EuroWestern understandings of child development (Moss, 2016; New, 2018). This is especially true for the education of many Indigenous children in Canada despite the fact that Indigenous families and communities have a strong history of raising and educating their children according to their own cultural values, in which children are

nurtured emotionally by parents and extended family members, fostered spiritually through language and cultural traditions, and educated to cultivate their interconnection to others and to Mother Earth.

The strengths and cultural traditions of Indigenous communities, including the care and education of children, were deliberately suppressed by the Canadian government's policy of assimilating Indigenous children to a European and Christian way of life through residential schools (Truth and Reconciliation Commission of Canada [TRC], 2015a, p. 629). Residential schools, operated by the Catholic and Protestant churches, had their basis in an image of the Indigenous child as uncivilized, savage, inadequate, and in need of intervention and correction (Greenwood, de Leeuw, \& Fraser, 2007; TRC, 2015a). Such “intervention” included not allowing children to speak their Indigenous language or engage in cultural ceremonies (TRC, 2015a). In addition to this, many children were emotionally, physically, and sexually abused by adults at the residential school who were supposed to care for them (TRC, 2015b). The "historical disadvantage and trauma" (Bezanson, 2018, p. 156) caused by residential school, and more current colonial practices, has meant that Indigenous children continue to experience significant inequities (Ball, 2012; TRC, 2015b) which are cumulative, persistent, and complex. Residential school's legacy 
of intergenerational trauma, for example, is perpetuated by more recent colonial injustices such as inadequate child welfare services on reserves (Bezanson, 2018) - resulting in a greater likelihood of children being removed from their home and community by child welfare services. And, a continued form of colonization is education built on Euro-Western ways of knowing and being which fail to meet the needs of Indigenous students (Battiste, 2013). Insofar as Euro-Western understandings of the child dominate early childhood education (Fleer, Chen, \& van Oers, 2018 Moss, 2016; New, 2018), it continues to be a colonial practice (Cannella \& Viruru, 2004; Taylor \& Pacini-Ketchabaw, 2015).

To counter the dominance of Euro-Western understandings of the child in early childhood education, one of the calls to action of the Truth and Reconciliation Commission of Canada (TRC, 2015c) is to "develop culturally appropriate early childhood education programs for Aboriginal families" (p. 2). However, to do so requires a knowledge of childhood in Indigenous contexts, knowledge which is held by Indigenous knowledge keepers such as Elders. The first step in responding to this action call is therefore the act of listening to Elders' teachings on childhood. However, coming to listen to and gain knowledge from Elders is an intricate and protocol-bound process that must be grounded in the community. To illustrate one such process in this article, I revisit and reflect on my master's research ${ }^{1}$ and thesis on Plains Cree Elders' images of the child (Akerman, 2010).

The article begins by attending to relationships through theoretical considerations of my research journey with the Elders. I outline the manner in which I engaged in the research - in both method and methodology-by turning toward Indigenous epistemology, ontology, and axiology and enacting these constructs by engaging in cultural protocols or ways of relating with the Elders in my research, as well as developing and maintaining relationships with them. I then examine some of the limitations of my research. This all serves as a point of reflection for those who wish to engage in research with Indigenous Elders for the purpose of informing curriculum making and pedagogy for Indigenous children. The article continues by sharing the Elders' images of the child that were so generously shared with me, discussing how I made sense of the Elders' teachings, and considering the implications of my research.

\section{Indigenous epistemology, ontology, and axiology}

I appreciate this opportunity to revisit my study (Akerman, 2010) regarding Plains Cree Elders' understandings of the child and to reflect on the epistemology, ontology, and axiology that I employed as a means of attending to relationships with the participants. When I engaged in my research journey, I relied on my intuition and life experience as a person of European and Quw'utsun descent to guide me, as well as on my relationships with Plains Cree community members. I strived to employ Indigenous epistemology, ontology, and axiology in my research, but did not extensively articulate it in the writing of my thesis by matching it to academic literature. Perhaps I did not explain such written commitments to an epistemology, ontology, and axiology because I could not yet easily articulate the Indigenous theoretical constructs that-although I was employing them-I had taken for granted. Nor could I articulate in writing that which I was still in the beginnings of learning (and to this day still am). These learnings of Indigenous worldview were born out of my relationship with my Quw'utsun grandfather and out of my four formative years pursuing my Bachelor of Education through the Saskatchewan Urban Native Teacher Education Program at the University of Saskatchewan. It makes sense to me now to rely on the writings of strong Indigenous (and non-Indigenous) scholars to help articulate my research journey and to help articulate and make sense of the theoretical constructs and methodology that I actually employed throughout my research.

In the past, research has primarily been done on Indigenous peoples rather than by or with Indigenous peoples (Smith, 2013). As a result, research has been a tool of colonization where the cultural values of Indigenous 
peoples were ignored (Lambert, 2014; Rigney, 2006). Such colonial research still occurs (Dei, 2013), although more research is being done with and for Indigenous communities (Gaudry, 2018; Kovach, 2016). It is with these histories in mind that I carefully planned my research project. I was astutely aware from the onset that in order for my research with the Plains Cree community to be fruitful, it had to derive from, as Cora Weber-Pillwax (2001) refers to, "Indigenous thinking and ways of being" (p. 169). Therefore, epistemology, ontology, and axiology were critical considerations of my research and they informed my choice of methodology and methods (Brayboy, 2018; Pidgeon, 2018; Wilson, 2008).

While cognizant that Indigenous ways of thinking and doing are diverse, I offer below some constructs of Indigenous epistemology, ontology, and axiology found in academic literature to illustrate how these longstanding theoretical constructs align with, and informed, my interactions with the Plains Cree Elders in my research. Acknowledging that there is no one universal paradigm of Indigenous thought or knowledge (Battiste, 2013), I do acknowledge that there are some commonalities. Since knowledge is relational and owned by the unique community from which it comes, these constructs would be best explored in a living group conversation where the ideas of the Plains Cree community in which I journeyed are shared and discussed (Adams, Wilson, Heavy Head, \& Gordon, 2015) rather than through this written text. Below then, are some ideas to consider, although decontextualized from the living dialogue of the community where the research took place.

\section{Epistemology}

During my research, I continually drew on my abecedarian understanding of Indigenous epistemology-born from my relationships with Indigenous people and the teachings of Indigenous scholars-to inform my actions as a researcher. Epistemology has been defined by Shawn Wilson (2008) as "the nature of thinking or thought" (p. 35). Bryan Brayboy and colleagues (2011) explain that Indigenous epistemologies "focus on the processes and qualities of relationships between and among humans and the world they inhabit" (p. 432). One inhabits "a web of connections and relationships" (Wilson, 2008, p. 77), and relationships with the land are as sacred as those with people (Wilson, 2008). A central aspect of my research, then, was to learn about these connections.

Marie Battiste (2013) speaks to the importance of connections in Indigenous research when she states that "Indigenous epistemology is holistic and acknowledges the interconnection of a person's physical, mental, emotional, and spiritual aspects and their relation to all living things" (p. 75). This interconnection of one's physical, mental, emotional, and spiritual aspects, for example, is often conceptualized by the medicine wheel, a traditional component of Cree culture that is best understood under the guidance of an Elder. Together, the four interrelated quadrants of the medicine wheel-physical, mental, emotional, and spiritual-allow one to interpret "their relation to all living things" (p. 75) in a holistic and informed manner. As Marlene Brant Castellano (2000) explains:

The medicine wheel is one of the most powerful instruments currently used to convey the holistic character of aboriginal knowledge and experience. The circle, representing the circle of life, contains all experience, everything in the biosphere-animal, vegetable, mineral, human, spirit-past, present and future. Two lines mark the quadrants of the circle. (p. 30)

The parts of the medicine wheel can only be understood in relation to the whole. Thus, the holistic nature of Indigenous epistemology influences the manner in which I, the learner, experience and analyze research data. Brant Castellano (2000) explains:

The holistic quality of knowledge implies that isolating pieces from experience and trying to make sense of them apart from the environment that gave rise to them flies in the face of reality and is bound to lead to frustration. This does not mean that analysis of parts of the circle are dismissed; it simply 
means that analysis must be balanced with synthesis-placing the part that we have come to know by close analysis in the context of all its relations, which will continually impact on that which we thought we knew, and thereby transform it. (p. 30)

Weber-Pillwax (2001) echoes Brant Castellano, stating that when an Indigenous scholar is "based in Indigenous reality and Indigenous ways of thinking, [they] start out with synthesis" (p. 168) and remain in synthesis during their learning journey. Synthesis, then, was well suited to the holistic nature of Indigenous knowledge and ways of knowing throughout my research.

When I synthesized Indigenous knowledge in my research with Elders, I paid heed to Indigenous knowledge that came from many sources and was acquired in various ways. To acknowledge this, I offer Brant Castellano's (2000) three sources of Indigenous knowledge which I attended to throughout my research: traditional teachings, empirical observation, and revelation. First, traditional knowledge-handed down from generation to generation, including creation stories, genealogies, tales, and spiritual teachings-teaches the values and beliefs unique to each community (Brant Castellano, 2000). Traditional knowledge, for example, is what I have received through oral tradition from my grandfather and from the Elders in my research. Second, I gained empirical knowledge during my research through careful observation interpreted "in the context of existing information" (Waldram, 1986, as cited in Brant Castellano, 2000, p. 23), based on my own observations and perspectives and those of others. This process allowed me to revise my understanding of what I observed. Third, revealed knowledge, which is spiritual in origin, is "acquired through dreams, visions, and intuitions" (Brant Castellano, 2000, p. 24), and at times in my research, I relied on my intuition to guide me. All three knowledge sources—traditional, empirical, revealed-are interconnected, and although I may receive them in different ways, they inform one another through synthesis.

\section{Ontology}

While epistemology has to do with the "nature of thinking" (Wilson, 2008, p. 35), ontology can be seen as the nature of reality (Wilson, 2008), and both epistemology and ontology rely on relationships. Wilson (2008) suggests that in Indigenous ontology, there is no one truth but multiple realities enacted in and born out of "different sets of relationships" (p. 73) and that a "relational way of being [is] at the heart of what it means to be Indigenous" (p. 80). As already stated, these relationships go beyond relationships with people. It is apparent that Indigenous epistemology and ontology can be considered one and the same when Wilson (2008) states, "it is not the realities in and of themselves that are important, it is the relationship that I share with the reality" (p. 74). Reality, then, cannot exist without relationships (Wilson, 2008). Through relationships with participants in my research, I came to learn about their realities, their truths.

\section{Axiology}

Setting out to learn about and care for participants' truths or realities in a good way requires a commitment to an axiology. Wilson (2008) defines axiology as "the ethics or morals that guide the search for knowledge and judge which information is worthy of searching for" (p. 34). Ethics, in turn, is defined by Willy Ermine (2007) as "the capacity to know what harms or enhances the well-being of sentient creatures" (p. 195). To develop the capacity to know how my actions would impact the participants, I had to be attentive to participants' worldviews and anticipate how my actions as a researcher might "infringe or violate the spaces of others" (Ermine, 2007, p. 195). This attentiveness was only possible through fostering my relationships with the participants in my research and my relationships with the wider Plains Cree community.

Attending to ethics can be difficult when the researcher and participants do not share a culture and therefore worldview. As Ermine (2007) states, "diverse human communities do not share a common moral vocabulary, nor do 
they share a common vision of the nature of human beings as actors within the universe" (p. 198). Acknowledging that researchers and communities do not always hold morals in common, Battiste (2013) warns of problems that arise when the researcher's ethical standpoint differs from that of the community in which they are researching:

Imposition of ethical rules derived from other epistemologies or ontologies or ways of life in other communities will inevitably cause problems in how one enters a community, what relationships guide the interactions, what knowledge is appropriate to be sought, how it is to be used, and other issues related to access and benefit, although common understandings and shared interests can be negotiated. (p. 71)

With this in mind, before committing to engage in research in the Plains Cree community, I had to first familiarize myself with the longstanding ethical directives and protocols of that community and, second, discern if I could adhere to these rules with a spirit of sincerity, openness, and good intent. This included engaging in protocols and behaviours that aligned with the community's cultural values (Smith, 2013).

Attending to the responsibilities that emerge from relationships with participants who operate from distinct and longstanding cultural values was a competing force for me as an academic researcher: I carried the responsibility of being accountable, not only to the community in which I was researching, but also to the academy (Brayboy et al., 2011). Because the academic institution is built on dominant Euro-Western notions of objectivity and truth, as well as the belief that knowledge collected through research can be owned by and claimed as the researcher's own, my Indigenous research methodologies had to, in the words of Michelle Pidgeon (2018), "go beyond standard ethical practices" (p. 5) of the institution and adhere to the ethical rules of the Plains Cree community in which I was researching. I learned the ethical rules unique to that community from community members, and these rules had implications from the beginning of my research when I accessed knowledge, to the dissemination and transmission of knowledge (Gaudry \& Lorenz, 2018). This sustained regard was particularly important in the area of knowledge dissemination, since in many Indigenous communities, as Robin Starr Minthorn and Heather Shotton assert, "not all knowledge is meant for public consumption" (2018, p. 211). Some knowledge is sacred and to be kept private, while some is public (Pidgeon, 2018). It was my responsibility as a researcher to learn the community's stipulations surrounding what knowledge can be shared, how it can be shared, and with whom. Ultimately it was my duty as a researcher to be a custodian of knowledge (Battiste, 2008), and this lifelong duty extends long past the written component (e.g., thesis, dissertation, scholarly paper) of my research project (Lavallée, 2009).

\section{Indigenous research}

Research within an Indigenous paradigm required me to develop and maintain a relationship with the Plains Cree people and community where my research was occurring, as well as to employ culturally informed methods (i.e., procedures to gather information) and methodologies (i.e., a philosophical framework) to tend to these relationships (Drawson, Toombs, \& Mushquash, 2017). In my Indigenous research, the line between method and methodology was sometimes blurred, with methods such as storytelling through oral tradition, for example, being more than just a method to gather information but a relational human interaction that was ceremonial, spiritual, philosophical, and, to a varied degree, communal in nature. In a sense, in my Indigenous research, method and methodology became interchangeable, and as Alexandra Drawson and colleagues (2017) suggest, embodied both a procedure and a framework.

Indigenous research methodologies, and the accompanying and intertwined methods, are many, which, according to Adam Gaudry and Danielle Lorenz (2018), represents the "plurality of Indigenous knowledges" (p. 22). With this plurality in mind, Lipe Kaiwipunikauikawēkiu (2018) states that "there is not one singular approach to 
Indigenous methodologies" (p. 209), just as there is no singular Indigenous lived reality or way of knowing. My Indigenous research methodology, then, allowed me and the Elders in my research to share our own stories in our own way (Minthorn \& Shotton, 2018). Given the agency Indigenous research provides to each individual Indigenous community, methodology and methods are fluid and changing, because they are formed and reformed to match the goals of the community where the research is occurring.

\section{Community-based participatory research}

Community-based participatory research, although not inherently Indigenous, is often used as a methodology for Indigenous research because it aligns well with Indigenous knowledge-sharing values in terms of community control and the caring for, and sharing of, traditional knowledge (Drawson et al., 2017; First Nations Information Governance Centre, 2014). I engaged in community-based participatory research because I was aware that, in the Plains Cree community where I was carrying out my research, ideas around community control and knowledgesharing values were prominent and well established. With this came the expectation that my research, in both method and philosophy, was done not only in consultation with but in relationship with the community, for the benefit of the community, and through participation of the community (Drawson et al., 2017; Gaudry, 2018). From the inception of my research, I continually worked to prioritize the needs of the Elders and of the wider Plains Cree community by listening to their wishes in order to fuel research decisions and directives. I strived for my research to be driven by what Drawson et al. (2017) refer to as "the underlying goal of collaboration, research equality, and community control" (p. 6), and I relied on the agency of community members to point out my shortcomings in addressing that goal.

Fostering community control of the research required me, the researcher, to depart from "motives of control and individual gain" (Brayboy et al., 2011, p. 434) and to prioritize service and communal good. Within this notion of service came reciprocity, where I, guided by the community, strived to provide for others around me in ways the community saw fit (Brayboy et al., 2011). According to Brayboy et al. (2011), such research is conducted "with a particular sense of humility; every legitimate relationship necessitates the discarding of egos and requires the researcher to recognize the responsibilities that emerge from the relationship" (p. 437). Two ways that I confronted my ego throughout my research were by recognizing a) my limited understanding of Plains Cree culture and b) the expertise and knowledge of community members whose participation, direction, and counsel were vital to the research process.

\section{Theoretical framework}

With my research relying on Indigenous epistemology, where knowledge and knowing are relational, and on an axiology and methodology that are centered on an attentiveness and commitment to relationships, it becomes clear that my theoretical framework is relational (Wilson, 2008). I am informed by the understandings of Wilson (2008), who states that a research paradigm is made up of the four "inseparable and blended" (p. 70) entities of "ontology, epistemology, axiology, and methodology" (p. 70). In my research, knowledge was gathered and synthesized through relationships, and, knowledge was later cared for with the relationships in mind. Belowfollowing a brief paragraph-are two sections which illustrate my relational theoretical framework in action: (1) "Engaging in Cultural Protocols and Ways of Relating" and (2) "Relationships as the Basis of my Research." What I share is my own unique and imperfect experience. It is intended to serve as a point of reflection and then departure.

The two main participants in my research (Akerman, 2010) ${ }^{2}$ were Helen ${ }^{3}$ and Margaret, both Elders and cultural advisors in a school division in western Canada in Treaty Six area where my research took place. Helen grew up in 
Chitek Lake First Nation (known as Pelican Lake First Nation) and learned her Plains Cree language and spirituality from her mother, who was a midwife. Margaret is from Thunderchild First Nation. She grew up learning her Plains Cree language and spirituality from her parents. Her mother was a midwife and herbalist.

\section{Engaging in cultural protocols and ways of relating}

Prior to my initial visits with Margaret and Helen, I visited members of the Plains Cree community to ask them about cultural protocols. When I use the term protocol, I don't mean hard and fast rules but the fluid, attentive, and culturally informed ways in which I related to Elders as my relationship with them and the community developed. In this sense, protocols are ways of relating, and I use these terms interchangeably. It was important that I inquired with people who personally knew Margaret and Helen, because the ways of relating expected from Elder to Elder often varies. A lot of these protocols I learned from community members ahead of meeting with the Elders, but some of then I learned as I communicated with the Elders and allowed their stories to inform how I should relate to them. Six main areas arose with regard to cultural protocol when seeking knowledge from the Plains Cree Elder participants.

The first was the wearing of a skirt. My choice to wear a long skirt was, for me, a way of honouring the traditions of a female Elder and her wishes for me to exercise my humility and honour myself as a woman who, like Mother Earth, can bear life. Margaret expected me to wear a long skirt when visiting her. Helen, on the other hand, appreciated my gesture of wearing a long skirt, but did not expect it.

The second way of relating was offering tobacco. For Plains Cree people, tobacco is a sacred plant that is interconnected to Mother Earth. I offered tobacco to honour each Elder's wisdom and allow her to comfortably and culturally express, through body language, whether or not she wished to participate in my research. When Helen and Margaret accepted my tobacco offerings, for example, they were expressing their desire to communicate with me and participate in my research. Illustrating the importance of relationship, particularly with Mother Earth, the Elders in my study eventually offered the tobacco in prayer and thanksgiving to Mother Earth, while also praying for me, the person who gave them the tobacco.

The protocols of offering tobacco varied from Elder to Elder in my research. For example, Helen told me how when she was a child she would only offer a small pinch of tobacco to her grandmother when she went to learn from her. From this indirect teaching through story, I knew I was to offer only a small pinch of tobacco when I visited Helen. Margaret, on the other hand, had her assistant tell me that the tobacco I offered her during our first visit was sufficient for all subsequent visits; I was not expected to offer her any more tobacco. During one visit, Margaret told me the importance of children sitting on the ground so they are close to Mother Earth. I asked her if it was best to offer her tobacco when we were both seated. "Yes," she replied:

When we're sitting on a chair, that's being close to Mother Earth too. And also, the Elder will not stand up. Well, they'll maybe stand up to greet you. But, if you're coming for a purpose, they'll tell you, "Let's sit down." And to us, sitting down you're more relaxed and you're more open to welcome, to receive, and give in that relationship.

From this I learned that I was to be seated when offering tobacco to an Elder.

The third way of relating was showing respect by offering the Elders transportation, nourishment, and accompaniment. When I met with Margaret for our first extensive visit, I picked her up from her home and took her out for supper at a restaurant. For those Elders who preferred to travel on their own, I was sure to greet them at the main entrance and accompany them to the room in which we were meeting. At the end of a gathering such 
as a talking circle, I would offer to carry their belongings to their vehicle for them, ensuring they made it to their vehicle safely and comfortably. This walk also gave me an opportunity to thank the Elder for their time spent with me and for the knowledge they shared. These ways of relating allowed me to show the Elders respect and acknowledge the mental and physical fatigue that can come from commuting, meeting new people, and sharing knowledge-activities Helen and Margaret undertook while of retirement age.

The care I provided for the Elders in my research resembled, in a small way, not only the care I have provided for my grandfather in the past, but also the care many Indigenous people provide for Elders in their community. For example, while attending Plains Cree powwows, I have noticed that Elders are offered accompaniment or a golf cart ride to the Elders' tent or lodge, where they sit in the shade and are served refreshments by younger community members. From observing this, I gathered empirical knowledge to learn how to care for and relate to Helen and Margaret in culturally appropriate and respectful ways. I then used this knowledge in my research by providing (or at least offering) transportation, nourishment, and accompaniment. Eventually a relationship developed where the Elders were willing to share their traditional knowledge with me. For me, gathering knowledge empiricallycoupled with good intent for the Elders and the community-was a precursor to being gifted with traditional knowledge.

The fourth way of relating was acknowledging that Elders are experts in their own right. When I set out to do my research, my topic focused on the Plains Cree image of the child from age 4 to 7 -the age range that early childhood education generally encompasses. Helen was quick to point out, however, that in a Plains Cree paradigm, where all life is valued, childhood begins at the moment of conception. My narrow focus on children aged 4 to 7 quickly broadened to include conception, birth, and infancy. Putting at the forefront the Elders' "underlying values" (Gaudry, 2018, p. 254) allowed my research to become more community based and participatory as it acknowledged the Elders' expertise. Further acknowledging the Elders' expertise, I did not ask initial questions of the Elders beyond "What is your understanding of the child?", since I did not have the traditional knowledge and experiences the Elders carried. Because of their wisdom, the Elders inherently knew what I needed to learn. I entered into learning sessions with them rather than interviews.

The fifth way of relating was determining whether I should record the conversations with the Elders. Helen did not want me to use an audio recorder when meeting with her. Asserting "tobacco is your computer," Helen explained that one of the reasons I offered her tobacco was to help me remember her teachings - the prayers she would later say while offering the tobacco to Mother Earth included prayers for my learning journey. Helen also said, "the really important information will stay with you." After each session, with Helen's permission, I would write down all I could remember of her teachings. From session to session, my listening skills improved, and I was able to recall more information, allowing me to partially experience some of the benefits of oral tradition.

The sixth protocol was to invite the Elders to remove from the final draft of my thesis information that was sacred or private. I slowly read the thesis draft to them as they listened and interjected when they wished. This allowed them to safeguard their Indigenous knowledge. For instance, I responded to Margaret's request to remove some spiritual teachings (or revealed knowledge) that she did not want included, because she preferred to share such teachings with a select audience and a public thesis would not allow this.

Learning about the specific protocols preferred by each Elder was a very important component of preparing to carry out my research. Ahead of meeting with an Elder, I would dialogue with a respected member of the Plains Cree community who would help me consider the Elders' worldview and the corresponding ways of relating that I could engage in to respect their worldviews (e.g., offering tobacco or not audio recording conversations). The more I learned about and followed the Elders' preferred ways of relating, the less I violated the Elders' spaces 
(Ermine, 2007) and the easier it was for me to enter into an ethically sound research relationship with them. Knowing each Elder's preferences allowed me to arrive somewhat prepared to interact with the Elder in a culturally appropriate way. This built respect because the Elders appreciated my efforts to accommodate them. Being unable to completely anticipate the specific protocols each Elder preferred placed me in a position of humility. I had to be open to making errors and, most importantly, I had to be receptive to the new learning opportunities these experiences provided.

I also learned about the preferred cultural protocols that the Elders expected me to follow by uncovering embedded teachings in the Elders' stories (such as how much tobacco to offer Helen). Brant Castellano (2000) explains that stories "teach without being intrusive, because the listener can ignore the oblique instruction or apply it to the degree he or she is ready to accept, without offence" (p. 31). Through stories, the Elders indirectly offered me instruction and correction, and it was up to me to be both perceptive enough to notice these directives and humble enough to accept them.

\section{Relationships as the basis of my research}

Before beginning my research on Plains Cree Elders' understandings of the child, I did not know Helen or Margaret. Coming to know and learning from them in a respectful way relied heavily on relationships-with them, with members of the wider Plains Cree community, and with Mother Earth. Wilson (2008) points out that for a researcher, being included in an Indigenous community depends on the researcher's past work and relationships in that community (and beyond) and on current work and relationships with community members. Echoing Wilson, Margaret Kovach (2016) emphasizes that "relational connections" (p. 36) are a key requisite of Indigenous research. Without my relational connections, I would not have had success in forming learning relationships with Elders Helen and Margaret. Throughout my research, I relied on my previous relationships with Plains Cree people in the school division where my research took place to lead me into new connections or relationships with community members and Elders, most importantly with Helen and Margaret. Such relationships were spurred through my ongoing interest and involvement in Indigenous education learning, as well as attendance at cultural gatherings, such as sweats, round dances, and powwows.

Relationships beyond the Plains Cree community also mattered. One such relationship was with my grandfather, who taught me through oral tradition when I visited him in British Columbia throughout my life. From our interactions, I knew that listening to and learning from Elders requires patience and time. When seeking information, I knew that I should not expect a direct response but should search for answers embedded in my grandfather's stories. This included stories that initially seemed irrelevant or unrelated to the topic at hand, and stories from years past.

Determining who is an Elder in an Indigenous community can be a difficult process, therefore I relied on recommendations from community members. Because some Elders carry a deeper traditional knowledge than others, I wanted to find Elders who were farther along in their journey as keepers of knowledge of Plains Cree childhoods. I visited respected personal contacts in the Plains Cree community in search of recommendations for appropriate Elders. During these meetings, Helen's and Margaret's names came up repeatedly. As a result, I was confident they were respected Elders who represented both the traditional and collective knowledge of their people.

My relationship with Ben, a Métis contact of mine whom I had known for several years, was integral to forming successful relationships with the Elders. Acting as a gatekeeper to Helen and Margaret, Ben asked me specific questions about my research to learn about my intentions. He wanted to know who would own the knowledge 
I gathered. I explained that the knowledge the Elders shared with me would continue to belong to them, while I served as a steward of their knowledge. Watching out for their best interests, Ben only helped me meet these Elders once he was sure I would treat them and the knowledge they offered in a culturally appropriate manner. He needed to be assured of this primarily to protect the Elders and very secondarily to protect his reputation as a community member. If I were to lack integrity when interacting with the Elders, it could reflect poorly on Ben, and he could be held accountable for my actions.

Under Ben's guidance, I arranged a talking circle with five of the school division Elders to share my intentions and gather their feedback. Helen and Margaret were two of the Elders present. In the days leading up to the talking circle, I visited each Elder individually to introduce myself and offer them tobacco.

The talking circle, which began with a smudge ceremony led by one of the Elders, proceeded according to Plains Cree tradition of using a stone to signify whose turn it was to speak. Passing the stone to the left, participants took turns speaking while others quietly listened. The Elders asked me questions regarding my research, and I explained my intentions. Among the Elders, there seemed to be a general consensus (not spoken, but implied) that my research was welcome in their school division. This was confirmed when, after the talking circle, the two lead Elders, Helen and Margaret, took interest in my topic and each invited me to meet with them at a later date.

The Elders' questioning during the talking circle, coupled with Ben's questioning of my research intentions, served, in a sense, as a rigorous Indigenous community advisory board that was enacted through the epistemology of a talking circle. This "board" was different from the board of ethics at my university because it served to protect the Elders and their intergenerational knowledge and was specific to their Plains Cree ways of knowing in a particular time and place. Most importantly, it brought me face to face with Ben and the Elders, affording them the opportunity to determine whether our relationship had a chance of advancing in a manner that protected and served the community and its intergenerational knowledge. Our relationship did stand a chance, and it developed into a teaching relationship where Helen and Margaret shared with me their Plains Cree understandings of children.

Gaining respect among the Elders through relationships with their contacts was not a one-time occurrence limited to the inception of my research, but rather was ongoing. For example, Stan, a Plains Cree acquaintance I had crossed paths with several times in the area of Indigenous education, helped me gain, or perhaps maintain, respect from Helen. One day when I was visiting with Helen at her workplace, Stan happened to walk into the room. He greeted Helen and then said, "Janine and her sister are great proponents of Indigenous education. They do good work." These kinship ties with my sister (with whom Helen was acquainted) and with Stan (whom Helen knew very well) offered the Elder some confidence in me as she actively discerned whether to continue sharing her knowledge with me.

\section{Countering limitations}

A key axiological challenge of my research was the consent form. In engaging Elders Helen and Margaret in informed consent, I had to find a way to be accountable to both the Elder participants and the university so I could carry out research that both respected the Elders and satisfied the institution. Having the Elders sign a consent form was considered to be very ethical by university standards, but by Indigenous standards it was incongruous and, given the colonial undertones of signing consent to use information or resources that Indigenous people own, inappropriate and potentially offensive. I had to find a way to get Indigenous protocols of consent "out in front" of the university consent form and to make the Indigenous protocols the primary driver of consent in my research. Once this was achieved, I could then position the consent form as a secondary, redundant, and clerical procedure. Although I had to use the consent form as a student of the university, I worked to make it auxiliary in nature in that 
informed consent, through gatekeepers and ultimately a talking circle, had already taken place before the consent form was signed.

Not only did the consent form have implications from the beginning of my research when consent was being obtained, it also had implications in the dissemination of knowledge (Gaudry \& Lorenz, 2018) long after the research had occurred. To be responsive to my relationship of trust with Helen and Margaret when disseminating the research, I found myself imposing relationally and culturally informed limitations on the consent forms the Elders had signed. Although the form outlined that the intended uses for the research findings included, but were not limited to, research articles, presentations, and teaching, I moved beyond the consent form to consider my perception of the Elders' preferences when deciding how to disseminate their teachings. For example, years after my thesis was completed, I was approached by a professor to share the Elders' teachings via video recordings to be shown in an online course. However, because Helen had wanted me to follow her custom of oral tradition and not audio-record her when she was teaching me, I deduced that she would not want me to share her teachings via video recordings. Consequently, I declined to share the teachings on video, even though the signed consent form would have allowed me to. I offered instead to share the Elders' teachings in a face-to-face class.

Declining to share the Elders' teachings via video recordings was a quick, intuitive response that I felt was right because I knew it would extend respect to the Elders, but it also caused me disappointment. This was because I highly respected the professor who invited me to share the Elders' teachings via video, and I dearly wanted to contribute to her work with the online course. She was a person of utmost integrity and she was acting with the good intention of contributing to culturally informed education for Indigenous families. I could not, however, put my relationship with her ahead of my relationship with the Elders. Inherent to the latter was my responsibility to continually ask myself, as Wilson (2008) suggests, "How am I fulfilling my role in this relationship? What are my obligations in this relationship?" (p. 177). Here, my role-my axiological commitment-was to care for the Elders' knowledge as I knew they would wish me to. These wishes and obligations lay not in the consent form, but in the whole of my relationship with them, the whole of my understandings of Plains Cree customs and beliefs and wider Indigenous beliefs, and in the whole of the traditional, empirical, and revealed knowledge I was holding. Returning to, and being attuned to, my relationship with the Elders and their cultural traditions, as well as determining what course of action would extend them the most respect, was an essential companion to the consent form.

Beyond the consent forms, other limitations to my research were not so easily countered. For example, presenting Helen's and Margaret's teachings in the format of an academic thesis in written English (with a very small amount of Cree throughout) rather than through oral tradition and entirely in Cree, was one such limitation. Here, I relied on institutionalized practices and the colonial language of English to inaptly "define Indigenous reality" (Battiste, 2008, p. 11). In light of this limitation, I acknowledge that my research, although intended to be Indigenous in nature, was the result of a carefully travelled path along two knowledge "systems" - the Indigenous tradition of intergenerational knowledge sharing and caretaking, and the Euro-Western academic system. I frequently sought Indigenous ways of knowing and doing rather than immediately defaulting to standard academic protocols.

\section{The participants}

Helen, a Plains Cree woman from Chitek Lake First Nation, Saskatchewan (known as Pelican Lake First Nation), grew up speaking Cree at home. She credits much of her learning of traditional Cree ways to her mother, who spoke only Cree and had no formal education. Her mother's knowledge and language were not recognized beyond the Indigenous community, and Helen felt that her mother had "no voice" outside the community, despite her vast knowledge as a midwife. Today, however, Helen says that her mother's voice is "loud and clear-louder than ever 
as I speak for her." Helen's father was English/Scottish. Helen's mother was baptized in order to marry him, yet she continued to practice Cree spirituality. Helen grew up practicing Cree spirituality and maintains this spirituality today.

Like her mother, Helen did not attend residential school. She explains that, because of the absence of residential school in her immediate family, her life is free from alcohol and drugs-substances she believes people have used to try and heal from the negative effects of residential school. When talking about her life without residential school, Helen explains, "That is why I am more comfortable. The church meant well, but the people who worked there [at the residential schools] were not healthy." Helen attended kindergarten to grade 12 at a school in a nearby farming community and then attended the Saskatchewan Indian Federated College.

Helen has five children, twenty-three grandchildren, and five great-grandchildren. She is an Elder and cultural advisor at a high school, and her many talents include beading, hide tanning, and tipi making/raising. Helen regularly shares tipi teachings, which she describes as "a woman's teaching," with other Indigenous women. She likens a tipi to a woman in that a tipi "stands with dignity and is powerful."

Margaret is from Thunderchild First Nation in Saskatchewan and both her parents were Plains Cree. Margaret's mother was a midwife and herbalist who spoke only Cree; her father spoke Cree and English. Margaret's first language was Cree. She attended grades 1 to 8 at St. Anthony Residential School in Onion Lake, Saskatchewan. When reflecting on her residential school experience, Margaret explains how the Cree parents and Elders at Thunderchild

tried to prepare children for their white cousins from the church that were going to join them. The Elders and parents tried to prepare their children about those Catholic teachings, but things were happening too fast ... too fast. The church came in too quickly and too fast.

When reflecting on what she believes the residential school's image of the child to be, Margaret says:

The culture of the child is not good, it's evil. "I'm going to change the children to the way I believe." Assimilate, I guess. So the people from the residential school were not ready. They didn't even want to listen to our teaching. You know, they didn't want to understand. They were just there to get the land. And change everybody to their way of believing, their way of living. That's how I saw it, and I believe I'm not the only one who began to understand that.

Margaret explains that regardless of what she learned in residential school, "the ways of teaching were different. More like, 'I know better and I'm teaching you and you learn what I'm teaching you or else."

Despite her eight years of attendance at residential school, Margaret is firmly grounded in her Cree spirituality. As a school child, she went home every summer to receive traditional teachings from her mother and other Elders in the community. It was these summertime teachings that fostered Margaret's Cree spirituality, as well as her traditional knowledge and skills she still practices today. Margaret smudges and prays every morning. Her traditional talents include sewing clothing such as ribbon shirts and dresses for ceremonies, quilting, beading moccasins, and drying wild moose, deer, and fish that her relations have hunted.

Margaret never attended high school because there was no high school in her community. Moreover, after years of attending residential school, she was not interested in leaving home to attend boarding school. Once married, Margaret worked on high school equivalency courses and then completed the Indian social work program at the University of Saskatchewan. She worked as a community health care worker for 20 years before her current role as school division Elder. Margaret considered furthering her university education, but was influenced otherwise 
by her father, who encouraged her to spend her time cultivating her traditional Plains Cree knowledge. She remembers her father saying that the knowledge she had gained from her "aunties, mother and Elders along the way is very important." Her father explained that there would be a lot of university-educated people in the future, but his people, the Plains Cree, were going to have very few keepers of traditional knowledge.

\section{Elders acknowledging ancestors}

When sharing knowledge with me, both Margaret and Helen continually acknowledged the ancestors or Elders who had originally passed on knowledge to them. For instance, before introducing a teaching, Helen and Margaret would say things such as "one of the things my mother and the great aunties taught me about ..." or "and in our way, and in our culture, what they would tell us is that ..." After giving a teaching, Helen and Margaret would make comments such as "so that's what my mother always told me" and "that's what my husband's grandmother used to say." When expressing her gratitude for "the teaching from the Elders" that she has received, Margaret remarked:

They have helped me. And even to this day I still believe in that. And, when I pray, I still thank the Creator for allowing me to know about these teachings. It's not that I know about everything, but I kept what I learned, and if I wasn't sure I would ask the older women.

\section{The Elders' image of the child}

The Elders' image of the child can be placed into six categories: (1) the child's awareness in the womb, (2) the child as powerful and pure at birth, (3) the child journeying through infancy, (4) the child's spirit as connected to Mother Earth, (5) listening to the child's voice, and 6) the child as a butterfly.

\section{The child's awareness in the womb}

Helen, who refuses to use the European word fetus and instead talks of "a child when in the womb," insisted that my research must consider the child from the moment of conception. Helen explained that "the child's spirit is asked to come down from above at the moment of conception." "Conception," she points out, "is the English word that is used." Helen describes pregnancy as a nine-month ceremony where the mother is with child or carrying a child, which is called kikiskahawasot in Cree.

Margaret and Helen shared many teachings about caring for a child while it is in the womb. Margaret taught, "It's not only when they're born that they remember things. A child has the power to remember when they're in the womb." Margaret shared this teaching from her grandmother-in-law:

She was a grand old lady, my late husband's grandma.... She was the one that continued the teaching about how to look after myself when I was pregnant. She would say, "Before you go to bed, sing to your baby, put your hands on your tummy and sing to your baby, or even in the morning when the sun comes, sing to your baby. And you ask your baby, 'Do you hear the birds singing?'” They listen. You are talking to your baby. And you nurture your baby through the umbilical cord. You nurture all four components: mental, spiritual, physical, and emotional ... and this nurturing transfers to your baby through the umbilical cord. And whatever you're singing, whatever you're talking, whatever you're feeling goes into that baby and they'll remember that.

Both Helen and Margaret believe that a child can remember experiences from their time in the womb. For instance, Helen's granddaughter remembers going berry picking with her mother while in the womb.

According to Helen, when a mother carries a child, everything the mother does, says, and thinks will affect the 
child. For example, if a mother uses foul language or belittles someone, the child she is carrying will hear this. Further, Helen spoke to the need for a mother to abstain from alcohol while "with child." Since a child's experience in the womb has direct implications for their journey to adulthood, Helen believes that a child's time in the womb should be "pleasant and beautiful" rather than "threatening." According to Helen, the necessary care while carrying a child "has been known by the Elders for a long time," but their knowledge has not been recognized because of their lack of formal university education.

\section{The child as powerful and pure at birth}

Margaret and Helen described the child as "powerful and pure" at birth. According to Margaret, a child illustrates this power when they raise their fist up and cry the moment they are born (English translation of Cree in brackets):

You know what my grandma told me a long time ago when I was a young lady about 14? "Someday you'll have babies and when they are born you'll notice that they have their little fists like this all the time, hanging onto something." And ... they tell you what they're hanging onto on their first cry, they tell you that. In Cree they say "esônikeyimiyan [the future is in my hands] and I have to protect it. I have to protect this future, but you have to help me. Mom and Dad, you have to help me." That is what every child is saying. "The future is in my hands and I need you to help me protect it."

Margaret explained how her mother and other women taught her to cleanse the child's hands with herbal oil right after birth to protect the future that rests in their hands. Further, she described the child "blessing" those present:

When they have their hands open, they are blessing you 'cause they're powerful, they're really pure. With their hands they're blessing the people around them in the house and their surroundings. That's what she used to tell us, that old lady. They're born pure, they're very powerful, so they're blessing you, talking to you and telling you you're receiving their blessings.

Helen also believes that the child is saying "I come with a gift" as they hold their fist in the air. This gift, which is unique to each child, is a talent to be used for the benefit of others. Acknowledging the spiritual power that the oskawâsis or newborn baby has, Helen explained that when one hears an oskawâsis cry, they are immediately attracted to the spiritual power and purity of that child.

Margaret told the story of when she was born, and how she was acknowledged as both "powerful and pure":

When I was being born my mother went through a lot of childbirth, you know it weakened her because of giving a lot of childbirth, and she was having problems with me. They asked this Kehtaya [Elder] in the community to come and do a ceremony to help my mom ... and then what he did was he put the pipe on my mother's tummy and invited me to come into the world. And he called me by my name. That was when I was named and called opipiwakeskwun. And that means when you see a bird flying in one spot, that's a thunderbird. When there's a light drizzle of rain sending down the powers, healing waters, that was why the thunderbird was flying in one spot. That's what I am named after ... opipiwakeskwun comes from the word Iskwew. Iskwew is a woman. See, already that old man knew I was a woman, a little girl. He invited me in the ceremony of birth. He invited me to come and then shortly after that I was born. He said, "In the future this baby will grow into a woman who is going to have this lodge, going to have to do this lodge." That's what he told my mother. And my mother told me that to help me ... those are the things that our culture did for babies, childbirth, those are the things that they did to help with childbirth. They give you to help in the natural way, and we call these the Creator's natural laws.

Margaret's story about her own birth - not shared here in its entirety-can only be fully understood-and is only intended to be fully understood-by those who have an extensive understanding of Plains Cree spirituality. 
Consequently, when I read the initial thesis document draft to Margaret, she retracted some of what she had initially shared with me about her birth so that that sacred information would not be published in my thesis. What all people can learn from Margaret's story, however, is that she was acknowledged as pure and powerful at birth.

\section{The child journeying through infancy}

Helen described infancy as "a sacred journey" in which the child learns to walk and talk. Both Margaret and Helen emphasized that, since infancy is a time where the child learns an abundance of new skills, it is important to carefully care for the child. Margaret shared that

children, from the time they are born, start studying. They start learning about their mother, that's the closest person that they have. He or she is being nourished by their mother ... for food and also, you know, being warm and fed and clothed and all this and loved and cared for. But at the same time they're already learning. They're watching, you know, and feeling their mother, and they want to do that. Even as little and young as they are, their eyes will wander. They'll test what they've seen. They do that and they even talk in their own little language and they think in their little minds. They even do that. And then they want to play and they love playing, especially if they get their mom laughing. You know they want that forever, and we have to let that with the children because that's their time and we have to respect and honour that. That's what I said, we have to learn patience ... and when they are about a year, two years old they want to do things. They want to help you. They want to please you.

Margaret believes that an infant's interactions with their mother is a meaningful time in the child's learning.

Carrying a child or placing a baby in a moss bag was an important part of childrearing for both Elders. A moss bag is traditionally made from hide and filled with dry soft moss. Moss bags have lacing all the way up the middle, allowing the parent to tie the laces so the baby is snug and secure. In modern times, moss bags are often decorated with beading. Margaret talked of her oldest son's memories of being in a moss bag:

He said, "I wonder how old I was?" He said, "I remember my grandmother putting me in a moss bag, taking my hand and putting it here and wrapping my hand so softly. And I remember taking my other one and putting it over, you know, after that and then I started getting really warm 'cause she was wrapping me that much." He said, "I remember that." And I said, "Well, did you see her?" He said, "Nope, but I know it was Grandma." [Margaret laughs.] I said it could have been me. [Margaret laughs] I wrapped all of my babies in moss. Moss, it grows in muskegs, and it's nice and soft.

Helen believes that infants, when in a moss bag, learn how to be patient and how to observe. Because they are not squirming and looking at their hands, they are able to see what is going on around them. They develop their senses of smell, sight, and hearing, and sleep better at night. According to Helen, moss bags can be used for infants up to about age one. Helen showed me a beautiful moss bag she was sewing. She also showed me pictures of herself and her granddaughter as infants in moss bags.

Helen shared the importance of properly holding an infant, or as she put it, "a sacred child." Helen's mother taught Helen to hold an infant by cradling him or her. Helen explained, "Don't carry an infant under your arm like it is a thing - that is not respectful." Instead, Helen said, "cradle the infant.... Don't prop a bottle and let the infant feed, rather, breastfeed to allow a physical bond." Helen's teachings on holding the sacred child reveal her high level of respect for the infant.

Helen believes that the infant has a very significant place in Indigenous ceremonies. She explained that in ceremonies where people are gathered in a circle, "the circle is not complete without the very young." As such, Helen invites and encourages mothers to bring their very young children into the circle. She is not concerned when infants crawl 
around and touch ceremonial objects because, in their purity, infants "purify the circle." "Once children begin walking on Mother Earth" Helen explained, "they can begin learning about how to act in a ceremony."

\section{The child's spirit as connected to Mother Earth}

Helen and Margaret acknowledge the child's spirit as being connected to Mother Earth and spoke to the importance of "teaching to the child's spirit." Helen defines the spirit of the child as "the whole child"-which includes the "emotional, mental, physical, and spiritual" dimensions of the child. The term Mother Earth is not something I myself can define. Rather, one can only begin to understand by listening to Elders' teachings. Margaret teaches that

Mother Earth has teachings from what's on and in her body, you know, the plants, the medicines, the food, even our clothing come from her and from the animals, as the white people call them, but us, we call them the grandfathers, the grandmothers. Even the sky life, she connects with the sky life because the birds that fly come on her breast to feed from her breast. We call her waters the seas, the lakes, the rivers, those are her breasts to us. Because if we didn't have that water we wouldn't live. We have to have that water. And we also have to have the sun 'cause the sun ... sends down the energy to every living spirit on earth and the sky life to help them live. So that is one of the reasons why the woman is connected to Mother Earth.... And our men, they sit down too when they do the ceremonies. Yeah, they sit down when they do the pipe ceremony and even in our lodges the men sit down. They connect with Mother Earth too.

It is significant that Margaret made note of the men sitting down. Generally, it is considered most important for women to sit close to Mother Earth, because they are recognized by the Creator as very powerful because, like Mother Earth, women can give birth. According to Margaret, women can "identify with Mother Earth 'cause only Mother Earth can bear and give birth to life.” Margaret explained further:

Grandmother the moon blessed us women and we can identify with her every 28 days. She's full moon every 28 days, and she gave us that gift, that we will become spiritual every 28 days. Because life is so sacred, so sacred.

In both English and Cree, Margaret expanded on women's bond with Mother Earth:

osâm ohci tâpiskoc kiya iskwew ehahâwasoyan ekwa enihtâwikihat ana awâsis [Because, just like you being a woman, you bear life, and you give birth to that child]. peyakwan kikâwînaw ehahâwasot pimâtisiwin ekanaweyihtahk enihtâwikitât kahkiyaw kîkway nipiy mîciwin [Just like our Mother bears life, she takes care of it / preserves it, gave life to everything, water, food]. That's how you are as a woman. You bear that life and give birth to that life. You give food to your child, nourish your child. That's how you're connected with Mother Earth.

Children, like adults, also have a special connection to Mother Earth because she provides many necessities for them, such as food and water. In the following passage, Margaret talked in both Cree and English about the benefits of children and adults alike sitting on Mother Earth:

Sitting down on the ground you will feel the energy of Mother Earth, the coolness of Mother Earth. You can feel the grass, you can just feel. kimôsihâw kikâwînaw kâhayapiyan waskanihk [You feel Mother Earth when you are sitting on her breast/chest]. You know, when you're sitting on her breast, you just feel Mother Earth. You feel her energy. sôhkisiwin kimôsihtân [You feel the strength]. It just goes in you 'cause you're connected to her.

When children sit on the floor of a classroom, rather than sitting on the ground outdoors, Margaret believes they are still connected to Mother Earth and can feel her energy. She believes that when teachers sit on the ground with 
children, they acknowledge everyone's connection to Mother Earth and acknowledge the child as equal to the adult. Margaret considers that, of all her grandmother's teachings, one of the greatest "is to be on the same level with the children," which most often involves sitting on the ground together:

My grandmother said, "Do not scare their spirits away by being so high as if you know more and you silence their spirit, they're not willing to learn. They feel so small. And they're scared to speak up. But when you get to their level they will share."

Margaret explained that when sitting at eye level with children, "you're more relaxed and you're more open to welcome, to receive and give that relationship." According to Margaret, children can

feel the energy of the care that you have for them because you're getting to their level. You're not standing up, like teachers do ... teachers mostly stand, and they walk around, and you have to follow them, you're moving your eyes. But the closeness and the caring that we were taught about teaching is sitting down with the children, being on the same level with them.

Helen also believes that children are equal to the teacher, and so teachers should sit down with the children and be at eye level with them. She cautioned against speaking loudly to children because this is often associated with trouble (e.g., at home). Helen believes children cannot hear or process what the teacher is saying when the teacher is yelling. She believes children should be talked to with a gentle voice, which will allow the teacher to speak and teach to the spirit rather than the mind. Helen believes teachers need to focus on the child's spirit rather than, for example, their clothes, or the fact that the child's parents may be living an unhealthy lifestyle. "When you touch the spirit," Helen explained, "the child, the awâsis, will learn."

\section{Listening to the child's voice}

Margaret and Helen both believe that a child has a lot of knowledge to share with others, and so they stressed the importance of "listening to the child's voice." Margaret shared that when adults sit with children, they are recognizing the child's ability to teach adults:

You're welcoming them ... you're being open to them and you're welcoming their sense of level, that you're not above them, that you do not know more than they do, but you're willing to share and willing to teach and willing to learn from them. That's what you're giving them. They can teach as well.

Margaret shared:

My grandchildren and my children have taught me how to care for them, and how to listen to them. They also taught me patience. Patience that in time they will want to learn what I want to share. But in the meantime, all I have to do is watch them, to look after them, to protect them and see that they don't get hurt. Those are the kinds of things they taught me. They taught me responsibility. They made it stronger. They made my caring stronger and they taught me how to listen to them.... And one of the things that I was told, too, is that when your children don't listen to you, you tend to start speaking louder and more sternly or even yelling at them and that's when you drive their spirits away. Because you don't have patience. You're not showing them that we need to take time together.

Margaret believes that when adults and children take time together, the child teaches the adult both patience and responsibility. It is the adult's role to diligently and openly accept these teachings.

Helen believes that a child's voice must be listened to from the moment they are conceived. When mothers with child ask, "What about me?" when overwhelmed by being with child, Helen reminds these mothers that there are now two lives, and the mother must do what is best for the child, who, is also asking "What about me?" Helen 
believes that mothers must care for the child in their womb in response. Helen acknowledges the difficulty that some mothers face but asserts that they must sit with Elders/grandmothers and receive knowledge, encouragement, and strength from them.

Helen believes a parent must allow their child to have a voice and to be heard. She cautions that when a child asks questions, the parent must notice and respond. If the parent is not able to answer the question, they may send the child to an Elder who can better address the question. Helen pointed out that a child "gets used to the rhythm of a parent's voice" and it becomes harder for them to internalize what their parent is telling them. Therefore, the parent, even if they are able to answer the child's question or give the child a teaching, may still go to an Elder and ask the Elder to teach the child. With the teaching coming from "a less familiar voice," the child will be more likely to listen to, and accept, the teaching. For example, Helen talked about a time when her daughter needed advice in a particular area. Helen had advised her several times, but her daughter did not appear to use or internalize her advice. So, Helen asked an Elder to give the same teaching to her daughter. Months later, at a gathering, Helen noticed that this Elder had quietly sought out her daughter and was speaking to her. Helen kept her distance, knowing that if her daughter saw her observing this, she might stop listening to the Elder. Later, Helen's daughter came to Helen and excitedly shared the seemingly new teaching the Elder had given her.

According to Margaret, children willingly communicate the areas in which they want to receive teachings, and it is the adult's responsibility to respond to these requests. For example, Margaret reflected on instances where children touch ceremonial objects which are meant to be off limits:

In ceremonies, I hear mothers say "Get away from that" before their children experience it and fulfil their curiosity. Let the children do that, touch the ceremonial object. And they'll ask, "What is this for?" And that's when your teaching comes in. They're asking for your teaching. They're asking for you to exercise your teachings. "What is this for?" Okay, you'll tell them that. "And why can't we touch them or play with them?" That's when you need to explain, "They're for ceremonies and that's the only time we use them. We'll do it together. I'll teach you how."

Recognizing the importance of responding to a child's curiosity, Margaret welcomes a child's curiosity in a ceremony because it is a great opportunity for a child to ask for, and receive, teachings.

\section{The child as a butterfly}

Margaret views the child as a butterfly who is free in spirit. She explained:

You look at a butterfly. They are so delicate. They're so soft and there's such beauty in them. You can see the purity in them and the beauty. And that's the way a child is, a child is free in spirit. Like their mind will go, you know, a child has the power to leave spiritually and still have life in their body, but they're flying around observing. That's how they know where they're gonna be and then they'll even think that “Hey, I was here before 'cause my mother was talking to me while I was in her womb." ... They have the ability to think and they'll store that. They're not forgetting it ... but they're storing it, in their little minds and in their hearts and in their senses.

The child as a butterfly analogy has direct implications for early childhood educators because it illustrates a child's need for flexible and free use of learning time in the classroom where the child can explore different learning opportunities at will:

Well, you look at a butterfly. Just watch a butterfly. It'll go to one leaf or maybe go to another flower. They'll have the taste of it, and they'll have the experience of touching that plant and then flying away and learning again and then they'll come back to where they were before. 
Like a butterfly, children's spirits flutter from one learning opportunity or thought to another. As such, Margaret cautions teachers that children will choose the amount of time they will pay attention to a task:

I always tell teachers when I go and talk to them that I'm not gonna force the children to stay two hours with me or an hour with me. 'Cause they have their own space, like we do. Sometimes we're sitting there and we're listening and then finally, you know, we're not listening at all 'cause already your spirit had enough and needed to go elsewhere to digest what we learn. And that's the same thing with children. But theirs is a shorter span because the spirit they're given is to learn and to pick up in different parts and different areas. And that spirit will go, it will wander off. You'll be talking there and the child will be there, but they're not really listening. So we have to respect and honour that.

Instead of scolding a child for not paying attention to the teacher during class, Margaret suggests that a teacher ask the child:

What is it that you had to experience? l'd like to learn about that. Are you willing to share, or can you talk about it sometime? It must be very interesting. I'd like to learn, and l'd like to know about it.

Margaret explained that when a child is faced with such questions from the teacher, "sometimes they'll come back and tell you more about it, sometimes they won't."

To determine the amount of time a child requires to complete a learning task, Margaret advises teachers to listen to the child's voice:

Our children, we're always told they're slow or behind coming from another school. But I always think they're not slow, they're not behind. It's the teachings that we had, we are given to be free, to be flexible with that child to allow them their time. Even ask them, "How long do you want to spend time with me?" Respect and honour that and they'll tell you. "Will you be able to get what I am gonna be teaching you in that time?" And they'll tell you.

This respecting and honouring of the child and the amount of time they wish to spend with a teacher further illustrates Margaret's and Helen's belief that children's voices need to be heard and responded to.

After being gifted knowledge from Helen and Margaret, I had much to reflect on. Next, in the "Discussion" section, I touch on a few ways that I made sense of their teachings.

\section{Discussion}

The image of the child the Elders shared with me is deeply rooted in their Plains Cree spirituality. Aligning myself closer to Plains Cree epistemology and whole-part relationships helped me make sense of the Elders' teachings, long after the research took place. This required me to be both perceptive and reflective along a lifelong learning trajectory, thus being a continually active, rather than passive, recipient of the Elders' teachings. Listening to the Elders' teachings, and making sense of them, was a continuous process of synthesis, spurring me to recollect all the "parts" of their teachings and connecting these parts in order to understand the "whole" of what they were saying. This required me, at times, to silently and contemplatively question the teaching of an Elder when it did not immediately make sense to me or to others. By thinking back to the Elders' previous teachings, I was able to synthesize connections among them, allowing me to discern answers to my query, or the query of others, and come to a fuller understanding of the teaching at hand.

Such an instance of synthesis was spurred by the questioning of a colleague, "John," after I shared with him Helen's and Margaret's understandings of the child as a butterfly. John, who very much appreciated the teachings, 
wondered if referring to children as butterflies belittled or essentialized them. I began to momentarily consider his concern regarding the possibility of belittling children. He, however, was not addressing the situation holistically. According to Brant Castellano (2000), "the holistic quality of knowledge implies that isolating pieces from experience and trying to make sense of them apart from the environment that gave rise to them flies in the face of reality and is bound to lead to frustration" (p. 30). Because John's thinking was informed by a EuroWestern epistemology in which animals and insects are considered less than human, he was initially unable to fully appreciate this Plains Cree teaching on children. After briefly considering John's point of view, I thought more holistically and acknowledged the equality of all living creatures when I recalled Margaret referring to animals as the "grandmothers" and "grandfathers" of the Plains Cree people:

Mother Earth has teachings from what's on and in her body, you know, the plants, the medicines, the food, even our clothing come from her and from the animals as the white people call them, but us, we call them the grandfathers, the grandmothers.

By referring to children as butterflies, Margaret respectfully acknowledges butterflies as family members. This respect for all of creation, not just humans, is echoed by scholars (Henderson, 2000; Steinhauer, 2002), including Cree scholar Sharon Venne (1998, as cited in Watts, 2013), who writes that all of life, including humans, animals, and plants, is an interdependent and "equal part of creation" (Watts, p. 23).

Being able to more fully appreciate the imagery of the child as a butterfly required me to stay distant from anthropocentricism and recognize the butterfly's place in the whole of Plains Cree creation. As suggested by James Waldram (1997) in Brant Castellano (2000), I was processing and interpreting information "in the context of existing information" (p. 23) in order to revise my understandings of the imagery of the child as a butterfly. This synthesis was a process in which one observation or experience informed another. In Battiste's (2013) terms, I was engaging in a "dynamic, living process of watching, listening, connecting, responding and renewing" (p. 121). This epistemological process required me, the recipient of knowledge, to be incisive, alert, and reflective, always revisiting the Elders' teachings and discerning the meaning behind their teaching as necessary.

Stories told by Elders often rely on the whole to understand the part. For example, the teaching on the butterfly, the part, relies on an understanding of creation and Mother Earth, the whole. The Elders' teaching on the child as a butterfly can be better understood when one is attuned to the whole of Plains Cree creation. Here I was not just a passive recipient of "traditional knowledge" on the Elders' teaching of the butterfly. Rather, I had to interpret this traditional knowledge in the context of my own empirical knowledge born out of my relationship with the Elders, and even in the context of revealed knowledge. For example, when my colleague suggested that imagining children as butterflies might be a way of essentializing children, I momentarily considered his viewpoint. I then followed my intuition, however, and challenged his suggestion by holistically referring to the butterfly as an equal part of creation.

Doing my best to attend to a holistic way of knowing in an Indigenous context throughout my research with the Elders required me, the learner, to recurrently seek knowledge from the Elders and the community and to continually synthesize this knowledge. Therefore, parachuting in and out of the community to hastily gather information that is specific "parts" confined to the research topic would not have sufficed. Without an extended relationship with Elders, continued teachings, and continued immersion into the community (by way of, for example, attending cultural events and ceremonies when welcomed), I would not have begun an earnest and fledgling journey toward a holistic understanding of the Plains Cree culture-and consequently would not have been positioned to begin to authentically make some sense of Elders' stories. The guidance of the Elders, community members, and ceremony served to holistically assist and inform me, the learner, as I interpreted and shared the Elders' stories. The more 
I immersed myself in the community, the more knowledge the stories offered me. Learning from the Elders' teachings required an extended commitment to learning Indigenous ways of knowing. This lifelong learning afforded me the skills to begin to decipher what was valued, and why, in the particular Plains Cree community in which I was welcomed, thus enabling me to synthesize and begin to make sense of the stories through either a borrowed Indigenous lens (as a non-Plains Cree learner) or an Indigenous lens (as a learner of Quw'utsun descent) rather than solely through a Euro-Western lens (as a learner of European descent and a student of the university).

\section{Moving forward: Implications}

The understandings of childhood shared through my learning journey with the Elders can serve to counter the dominance of Euro-Western understandings of the child in early childhood education and offer a starting point to address the TRC's (2015c) call to action to develop culturally appropriate early childhood education programs for Indigenous families. Culturally appropriate early childhood education for the Plains Cree community in my study, for example, incudes acknowledging children's spirits as connected to the land that is Mother Earth. As recommended by Helen and Margaret, this involves ongoing opportunities for children to engage in education that is led by Elders, is land based, includes Indigenous language, and allows the child opportunities to be free in spirit, since, land, language, and the child's spirit are all inextricably interconnected. It is important to note that my research is specific to one of many Plains Cree communities, and research with other Indigenous communities is needed to address the TRC's $(2015 \mathrm{c})$ call to action.

Providing culturally appropriate early childhood education for Indigenous children will require reconfigurations of educational systems built on colonial perspectives and a shift to systems based on local Indigenous community knowledge and culturally informed ways of understanding and teaching children (United Nations, 2008). Decolonizing education requires structural changes but also local classroom-level changes that can be enacted by curricular leaders and teachers in relationship with local Indigenous communities and Elders. In addition to sharing the Elders' teachings, my research addressed the question: "In what ways can educators build and maintain relationships with local Indigenous communities and Elders in order to inform their understanding of the Indigenous children they teach?" My research process, where I forged relationships with community membersspecifically Elders-can serve as a point of reflection on how others might consider their own way of going about relationship building over a continuum of time in order to inform curriculum making.

Once relationships are established with Indigenous communities and Elders, and if knowledge on Indigenous childhoods is shared, the Elders will have specific preferences for how this knowledge is disseminated to educators. For example, after the Elders in my research shared their knowledge with me, they asked that I, with help from the community, organize a talking circle in which the Elders shared their teachings with some of the Plains Cree early childhood teachers from the school division where my research took place. This talking circle provided an opportunity for the Elders and teachers to reflect on ways that these teachings could culturally inform their interactions with their Plains Cree students. At the request of the community, I also presented the Elders' teachings to early childhood teachers in the division and to the Early Learning Committee. My involvement is a very minute component of the countless ways in which the division equips teachers to provide culturally informed education for Indigenous students, such as regular opportunities for teachers to attend public Indigenous celebrations that undoubtedly inform the teachers' ongoing relationships with Elders and the wider Indigenous community.

Both Margaret and Helen emphasized that learning is a lifelong journey, and so my research should not be conclusive in nature. Cared for and kept alive through oral tradition for generations and held in high regard by community members, the Elders' teachings do not need a conclusive analysis to accord their teachings legitimacy. 
It is the Elders' words that should resonate with the reader as they travel their own journey of learning about Plains Cree childhoods and, more broadly, Indigenous childhoods, and reflect on how these teachings can inform early childhood curriculum and pedagogy. The importance placed on learning as a lifelong journey was summed up by Helen, who, with a nod of agreement from Margaret, said, "We are thankful for the words that our ancestors have left behind and believe that these words will continue to teach."

Note: This research was supported by the Social Sciences and Humanities Research Council of Canada.

\footnotetext{
1 When I refer to "my research," I respectfully acknowledge that it is more accurately described as "a shared learning journey with Elders and the Plains Cree community where I was gifted with ancestral knowledge." For ease of reading and due to the lack of a succinct term, I use "my research" instead.

2 Portions of this paper were drawn from Akerman, 2010 (my master's thesis).

${ }^{3}$ Pseudonyms were used for all participants in the study.
} 


\section{References}

Adams, D. H., Wilson, S., Heavy Head, R., \& Gordon, E. W. (2015). Ceremony at a boundary fire: A story of Indigenist knowledge. Sydney eScholarship Repository.

Akerman, J. (2010). The image of the child from the perspective of Plains Cree Elders and Plains Cree early childhood teachers (master's thesis). https://era.library.ualberta.ca/files/p8418q00h\#.VpBc-JMrJ7M

Ball, J. (2012). Federal investments in strengthening Indigenous capacity for culturally based early childhood education and care. In N. Howe \& L. Prochner (Eds.), Recent perspectives on early childhood education and care in Canada (pp. 337-366). University of Toronto Press.

Battiste, M. (2008). Research ethics for protecting Indigenous knowledge and heritage: Institutional and researcher responsibilities. In K. Norman, Y. S. Denzin, S. Lincoln, \& L. T. Smith (Eds.), Handbook of critical and Indigenous methodologies (pp. 497-510). SAGE. https://dx.doi.org/10.4135/9781483385686

Battiste, M. (2013). Decolonizing education: Nourishing the learning spirit. Purich.

Bezanson, K. (2018). Caring society v. Canada: Neoliberalism, social reproduction, and Indigenous child welfare. Journal of Law and Social Policy, 28, 152-173. https://digitalcommons.osgoode.yorku.ca/jlsp/vol28/iss1/8/

Brant Castellano, M. (2000). Updating Aboriginal traditions of knowledge. In G. Sefa Dei, B. Hall, \& D. Rosenberg (Eds.), Indigenous knowledges in global contexts: Multiple readings of our world. (pp. 21-36). University of Toronto Press.

Brayboy, B. (2018). Foreword. In R. S. Minthorn \& H. J. Shotton (Eds.), Reclaiming Indigenous research in higher education. (pp. ix-xxi). Rutgers University Press.

Brayboy, B. M. J., Gough, H. R., Leonard, B., Roehl, R. F. II, \& Solyom, J. A. (2011). Reclaiming scholarship: Critical indigenous research methodologies. In S. D. Lapan, M. T. Quartaroli, \& F. J. Riemer (Eds.), Qualitative research: An introduction to methods and designs (pp. 423-450). Jossey-Bass.

Cannella, G., \& Viruru, R. (2004). Childhood and postcolonization. RoutledgeFalmer.

Dahlberg, G., Moss, P., \& Pence, A. (2013). Beyond quality in early childhood education and practice: Languages of evaluation (3 ${ }^{\text {rd }}$ ed.). RoutledgeFalmer.

Dei, G. J. S. (2013). Critical perspectives on Indigenous research. Socialist Studies, 18(3), 27-38. https://doi.org/10.18740/S47G64

Drawson, A. S., Toombs, E, \& Mushquash, C. J. (2017). Indigenous research methods: A systematic review. The International Indigenous Policy Journal, 2(8), 1-25. https://doi.org/10.18584/iipj.2017.8.2.5

Ermine, W. (2007). The ethical space of engagement. Indigenous Law Journal, 6 (1), 193-204. https://jps.library.utoronto.ca/index.php/ ilj/article/view/27669/20400

First Nations Information Governance Centre. (2014). Ownership, control, access and possession (OCAP $\left.{ }^{\mathrm{mm}}\right)$ : The path to First Nations information governance. https://fnigc.ca/sites/default/files/docs/ocap_path_to_fn_information_governance_en_final.pdf

Fleer, M., Chen, F, \& van Oers, B. (2018). New directions in early childhood education practice: International developments and practice gaps. In Fleer, M \& van Oers, B. (Eds.), International handbook of early childhood education (pp. 955-966). Springer Nature.

Gandini, L. (2004). Foundations of the Reggio Emilia approach. In J. Hendrick (Ed.), Next steps toward teaching the Reggio way: Accepting the challenge to change (pp. 13-26). Pearson.

Gaudry, A. (2018). Epilogue: Next steps in Indigenous community-engaged research: Supporting research self-sufficiency in Indigenous Communities. In K. Thor Carlson (Eds), Towards a new ethnohistory: Community engaged scholarship among the people of the river. In K. T. Carlson, J. S. Lutz, Naxaxalhts'i, \& D. M. Schaepe (pp. 254-258). University of Manitoba Press.

Gaudry, A., \& Lorenz, D. (2018). Indigenization as inclusion, reconciliation, and decolonization: Navigating the different visions for Indigenizing the Canadian academy in Indigenous communities. AlterNative, 14(3), 218-227. https://doi. 
org/10.11771177180118785382

Greenwood, M., de Leeuw, S., \& Fraser, T. N. (2007). Aboriginal children and early childhood development and education in Canada: Linking the past to the present and the present to the future. Canadian Journal of Native Education, 30(1), 5-21.

Højholt, C. (2018). Introducing reflections. In M. Fleer \& B. van Oers (Eds.), International handbook of early childhood education (pp. 471-482). Springer Nature.

Henderson, J. Y. (2000). Ayukpachi: Empowering Aboriginal thought. In M. Battiste (Ed), Reclaiming Indigenous voice and vision (pp. 248-278). UBC Press.

Kaiwipunikauikawēkiu, L. (2018). Toward equity and equality: Transforming universities into Indigenous places of learning. In R. S. Minthorn, \& H. J. Shotton, (Eds.), Reclaiming Indigenous research in higher education (pp. 162-177). Rutgers University Press.

Kovach, M. (2016). Moving forward, pushing back: Indigenous methodologies in the academy. In N. K. Denzin \& M. D. Giardina (Eds), Qualitative inquiry through a critical lens (pp. 31-39). Routledge.

Lambert, L. (2014). Research for Indigenous survival: Indigenous research methodologies in the behavioral sciences. Salish Kootenai College Press.

Lavallée, L. F. (2009). Practical application of an indigenous research framework and two qualitative Indigenous research methods: Sharing circles and Anishinaabe symbol-based reflection. International Journal of Qualitative Methods, 8(1) 21-36. doi: $10.1177 / 160940690900800103$

Malaguzzi, L., Castagnetti, M., Giudici, C., Rinaldi, C., Vecchi, V., Moss, P. ... \& McCall, J. (2016). Loris Malaguzzi and the schools of Reggio Emilia: A selection of his writings and speeches, 1945-1993. Routledge.

Minthorn, R. S., \& Shotton, H. J. (2018). Conclusion: Repositioning the norms of the academy: Research as wisdom. In R. S. Minthorn \& H. J. Shotton (Eds.), Reclaiming Indigenous research in higher education (pp. 206-214). Rutgers University Press.

Moss, P. (2016). Why can’t we get beyond quality? Contemporary Issues in Early Childhood, 17(1), 8-15. https://doi. org/10.11771463949115627895

New, R. (2018). Rethinking curriculum as imagined childhoods. Journal of Early Childhood Studies, 2(2), 364-382. https://doi. org/10.24130/eccd-jecs.196720182274

Pidgeon, M. (2018). Moving between theory and practice within an Indigenous research paradigm. Qualitative Research, 1-19. https:// doi.org/10.11771468794118781380

Rigney, L. I. (2006). Indigenist research and Aboriginal Australia. In J. E. Kunnie \& N. I. Goduka (Eds.), Peoples' wisdom and power: Affirming our knowledge through narratives (pp. 32-48). Ashgate.

Smith, L. T. (2013). Decolonizing methodologies: Research and Indigenous peoples ( $2^{\text {nd }}$ ed.). University of Otago Press.

Steinhauer, E. (2002). Thoughts on an indigenous research methodology. Canadian Journal of Native Education, 26(2), 69-81. https:// www.researchgate.net/publication/234718488_Thoughts_on_an_Indigenous_Research_Methodology

Taylor, A., \& Pacini-Ketchabaw, V. (2015). Introduction. In A. Taylor \& V. Pacini-Ketchabaw (Eds.), Unsettling the colonial places and spaces of early childhood education (pp. 1-17). Routledge.

Truth and Reconciliation Commission of Canada (TRC). (2015a). Canada's residential schools: History, part 1. Origins to 1939. Final report of the Truth and Reconciliation Commission of Canada (Vol. 1). http://www.trc.ca/assets/pdf/Volume 1_History Part 1 English Web.pdf

Truth and Reconciliation Commission of Canada (TRC). (2015b). Honouring the truth, reconciling for the future: Summary of the final report of the Truth and Reconciliation Commission of Canada. http://www.trc.ca/assets/pdf/Honouring the Truth Reconciling for the Future July 23 2015.pdf

Truth and Reconciliation Commission of Canada (TRC). (2015c). Truth and Reconciliation Commission of Canada: Calls to action. http:// 
trc.ca/assets/pdf/Calls to Action English2.pdf

United Nations. (2008). United Nations declaration on the rights of Indigenous Peoples. https://www.un.org/esa/socdev/unpfii/documents/ DRIPS en.pdf

Watts, V. (2013). Indigenous place-thought and agency amongst humans and non humans (First Woman and Sky Woman go on a European world tour!). Decolonization: Indigeneity, Education and Society, 2(1), 20-34. https://jps.library.utoronto.ca/index. $\mathrm{php} /$ des/article/view/19145

Weber-Pillwax, C. (2001). Orality in northern Cree Indigenous worlds. Canadian Journal of Native Education, 25(2), 149-165.

Wilson, S. (2008). Research is ceremony: Indigenous research methods. Fernwood. 